\title{
FALLEN WOMEN AND THE LONDON LOCK HOSPITAL LAWS AND BY-LAWS OF 1840 (REVISED 1848)
}

\author{
María Isabel Romero Ruiz* \\ University of Málaga
}

\begin{abstract}
The nineteenth century witnessed a buge increase in both private and public institutions to control and to contain two elements deemed to be the most dangerous in British society: the prostitute and the fallen woman. These individuals were considered deviant at a time when the middle-class exercised philanthropy supporting the double standard code of morality. Charity and state intervention were carried out by two kinds of institutions which were closely connected: lock hospitals and lock asylums. However, the role of lock hospitals was to cure venereal disease, whereas the role of the lock asylums was the reformation and instruction of these women. As a consequence, this paper seeks to examine the importance of the London Lock Hospital and Asylum Laws and By-laws of 1840, especially in relation to female patients and penitents, so as to ascertain the roles of these two institutions in the reproduction of the moral standards of the middle-class and of the religious discourse of the time. We shall see that these regulations reflect the ideas of industriousness, repentance and atonement for these women's past lives, emphasizing the differences between the sexes as far as sexual and moral behaviour were concerned.
\end{abstract}

Keywords: fallen women, venereal disease, lock hospital, lock asylum, philanthropy, double-standard code of morality.

* Correspondence should be sent to: Dr. María Isabel Romero Ruiz. C/Pintor Francisco Boigas Aguilar, 10, 29016-Málaga. Spain. Email: mirr@uma.es 


\title{
MUJERES CAÍDAS Y LAS NORMAS DEL HOSPITAL DE ENFERMEDADES VENÉREAS Y DEL REFORMATORIO DE MUJERES DE LONDRES DE 1840 (REVISADAS 1848)
}

\begin{abstract}
RESUMEN. El siglo XIX fue testigo de de un enorme incremento en instituciones tanto públicas como privadas para controlar y contener dos de los elementos más peligrosos de la sociedad británica: la prostituta y la mujer caída. Estas mujeres eran consideradas desviadas en una época en que la clase media ejercía la filantropía siguiendo un doble código de moralidad. La caridad y la intervención estatal se llevaban a cabo por medio de dos instituciones que estaban intimamente relacionadas: los hospitales de enfermedades venéreas y los reformatorios de mujeres. Sin embargo, el papel de estos hospitales era el de curar enfermedades venéreas, mientras que el de los reformatorios era la reforma e instrucción de estas mujeres. Como consecuencia, este artículo trata de examinar la importancia de las normas del Hospital de Enfermedades Venéreas $y$ del Reformatorio de Mujeres de Londres de 1840, especialmente en relación a las pacientes femeninas y penitentes con objeto de establecer los roles de estas dos instituciones en la reproducción de los valores morales de la clase media y del discurso religioso de la época. Veremos cómo estas normas reflejan las ideas de diligencia, arrepentimiento y expiación por sus vidas pasadas, enfatizando las diferencias entre los sexos en lo que se refiere al comportamiento moral y sexual.
\end{abstract}

Palabras clave: mujeres caídas, enfermedad venérea, hospital de enfermedades venéreas, reformatorio de mujeres con enfermedades venéreas, filantropía, doble código moral.

Received 1 May 2010 Revised version accepted 16 June 2010

\section{INTRODUCTION}

The aim of this paper is to analyse the role of the London Lock Hospital and the London Lock Asylum in their effort to contain and control two of the elements in Victorian society which were perceived as most dangerous: the prostitute and the fallen woman. ${ }^{1}$ Both were considered deviant and these two charitable institutions tried to exercise an influence on these women's behaviour through a set of regulations known as the Laws of the London Lock Hospital and Asylum.

1. This article is based on a paper delivered at the Social History Society Conference held at the University of Warwick, 3-5 April 2009. 
Like many other nineteenth-century institutions and organizations, the London Lock Hospital and Asylum reproduced a double-standard code of morality which established that there were separate spheres for men and women. Men belonged to the public sphere of business, politics and work, and women belonged to the private sphere of home and family. For this theory, the image of the asexual respectable woman was determining, and female pleasure was defined in relation to marriage and reproduction; the notion of purity was essential for the single-code of sexual morality, based on the model of female sexual restraint. Thanks to this ideology behind the sexual nature of women, they could be the guardians of the private sphere and the keepers of the domestic and social order. Respectability was also associated with certain modes of behaviour, language and appearance, and with traits like dependency, delicacy and frailty (Nead 1988: 19-29).

The role of the lock hospital was to cure venereal disease, and the role of asylums was to provide deviant women with a moral cure. Men and women underwent a treatment for venereal disease in the Lock Hospital, but only women received a moral cure in the Lock Asylum, as men had a natural sexual impulse which they could not control because it was innate in them, but women were held to be responsible for the purity of the nation, therefore they had to be chaste. The concept of chastity in women was based on two principles: woman's place and woman's special nature. Woman's place had to do with the preservation of the purity of the English breed "as the channel through which the property passed" (Mitchell 1981: xi). Woman's nature was connected with her moral superiority and her lack of sexual appetite. In lock asylums women were taught appropriate behaviour through religious instruction, and a decent working-class profession, so that a process of inclusion in respectable society would be fulfilled after a process of exclusion had taken place in an institution that was run according to middleclass values.

Although David Innes Williams in his 1995 book, The London Lock: A Charitable Hospital, 1746-1952, writes a careful history of the Hospital from its foundation in 1746 to its closure in 1952, analysing different periods in relation to aspects such as the treatment of venereal disease, medical theory and practice, the patients, the staff, the governors, finance, the Chapel and chaplains, the buildings and the situation of the Hospital and Asylum at the different stages of their existence, there are other aspects which need further consideration. Those aspects concerning the female patients and penitents and the social and moral implications of the treatment of Victorian prostitutes and fallen women were especially important. His work as well as mine is based on the archives of the London Lock Hospital and Asylum that have survived and are kept at the Royal College of Surgeons of England Library in London. 
Other scholars have also focused their attention on different reform institutions and hospitals. One of them is Judith Walkowitz, who writes about the Royal Albert and the Royal Portsmouth, two hospitals which had lock wards for women in Southampton and Portsmouth respectively in her book Prostitution and Victorian Society: Women, Class and the State (1980); also Frances Finnegan in her volume of 1979 entitled Poverty and Prostitution: A Study of Victorian Prostitutes in York talks about rescue and reform at the York Penitentiary. This Penitentiary had many similarities with the London Lock Asylum, regarding the running of the institution, its fund-raising propaganda and its aims in reforming and teaching prostitutes and fallen women; Linda Mahood in The Magdalenes: Prostitution in the Nineteenth Century (1990) deals with the Glasgow Lock Hospital and Asylum in several chapters as an example of a Scottish institution for the reform and cure of Victorian prostitutes. Finally, Frances Finnegan has published another book, Do Penance or Perish: A Study of Mgadalen Asylums in Ireland (2001) which deals with the history of Magdalen institutions in Ireland; she establishes a comparison between the English and the Irish systems, highlighting the importance of the Catholic element in the latter, which made rescue work of deviant women a completely different matter. However, I have chosen to focus this article on the London Lock because it was one of the first institutions of its kind in Britain and one of the most important, and has systematically been ignored in the scholarly work that has been done on institutions of this type in the last decades.

In this paper, I will closely examine the Laws of the London Lock Hospital and Asylum of 1840 and revised in 1848, and will analyse the way in which these norms reproduce the moral standards of the middle-class and of the religious discourse of the time. Also, evidence will be shown as to the existing differences concerning gender and class in the way these laws and by-laws were applied. As a consequence, women and not men were the objects of discrimination and reformation in lock asylums and penitentiaries, and of instruction in propriety and a decent working-class profession.

\section{THE HISTORY OF THE LONDON LOCK IN THE NINETEENTH CENTURY}

Throughout the nineteenth century, several institutions ranging from penitentiaries and asylums to specialised homes were founded by middle-class philanthropists to rescue and reform prostitutes. Significantly, similar institutions were not created for men who had had recourse to prostitution as an escape for their perceived sexual needs. The prostitute was defined in Victorian discourses as a woman who had been seduced and abandoned, with no friends. She had to turn to prostitution to earn her living, thus entering a downward path which led to a ruined constitution and a premature death. She became an outcast and a social 
victim, but at the same time she was represented as a figure of contagion and disease that had to be controlled and contained. There were no clear boundaries between prostitutes and fallen women, being these last two words a kind of euphemism for the first, although the concept of fallen women was usually associated with the middle-class. In Lynda Nead's words:

The category of 'prostitute' was not fixed or internally coherent; it was accommodating and flexible and could define any woman who transgressed the bourgeois code of morality. The prostitute was understood in terms of her difference from the norm of respectable femininity: if the feminine ideal stood for normal, acceptable sexuality, then the prostitute represented deviant, dangerous and illicit sex. (1988: 94-95)

Nonetheless, the term used for working-class women who regularly gave sexual favours to clients in return for money was prostitute, and the fallen woman was usually a middle-class woman who had been seduced and abandoned, sometimes even with a child, who was stigmatized and had to work as a dressmaker or a governess - the typical middle-class women's professions-in order to survive.

Penitentiaries were the hallmark of both the Established Church of England and the Roman Catholic Church and were involved in the reform of prostitutes and fallen women using the penitential system of incarceration and punishment of inmates. In the middle of the century, the number of penitentiaries increased with the formation of the Church Penitentiary Association (CPA) inspired by the Oxford Movement. Due to an evangelical revival which advocated an alternative system of rescue work based on a family system instead of a penitential one, homes for fallen women began to flourish. (Bartley 2000: 25-26) Homes for fallen women were often called Magdalen Homes, following the Biblical reference to Mary Magdalen. Paula Bartley argues that the name bome for these institutions had connotations of domesticity, being seen as woman's natural environment, but also of comfort and support, the number of inmates being considerably inferior in comparison with penitentiaries. (2000: 30) Power relations were still present as women were made dependent and submissive, and male and middle-class control was exercised over them. They were subject to a strict discipline and forced to behave as children who depended on their moral superiors. It was obviously the middle-class concept of home that was reproduced, and most of these girls came from disrupted families which had never constituted a proper home.

Not only homes and penitentiaries but also lock hospitals taught women submissiveness and patriarchal values, accepting the supervision of the medical officer and then the matron, who was set as an example of proper feminine behaviour. Differences of sex and class were reinforced in these hospitals. (Walkowitz 1991: 221) Again, women were taught middle-class social and moral 
values, and were trained to return to the private sphere as domestic servants. However, many lock hospitals added an asylum to their installations for those women cured of venereal disease who wanted to devote two years of their lives to being morally reformed via a period of instruction which would turn them into decent working-class women. Asylums were very similar to homes in their organization and structure.

Those fallen women who were pregnant or diseased were not so lucky. They were not accepted in Lock Asylums or Magdalen Homes. Their only place to go, if they were destitute, was the workhouse. After the New Poor Law of 1834, workhouses were built throughout England to provide the poor with in-door relief. This law abolished out-relief to unsupported women, who were the second largest group in workhouses. Among them, abandoned women, domestic servants between jobs, widows and women of low character could be found. For groups ranging from young women who were pregnant or diseased to hardened prostitutes, workhouses were the only place to seek relief. (Longmate 2003: 156193) Life was harsh inside the workhouse: inmates had to wear uniforms, they had to do tiring, monotonous jobs like picking oukum-- which consisted in untwisting and picking the yarn out of the old ropes--, bone-breaking or stone-breaking, and women and children in particular had to get involved in hard domestic chores. The diet was clearly insufficient and the food was uneatable. The discipline and system of punishment were almost unbearable. These places were most hated by the poor and they called them "the Bastilles".

With the Contagious Diseases Acts of 1864, 1866 and 1869, women venereally diseased were taken into lock wards or lock hospitals to be treated. ${ }^{2}$ Some of these women when they were cured and some of the pregnant girls after having had their babies were accepted in lock asylums. For that, they needed to show that they had an inclination for reformation and a docile nature that would, the hope was, allow the Institution to indoctrinate them in such religious and moral values as prevailed in middle-class discourses.

The London Lock Hospital and the London Lock Asylum were merely two of the first charitable institutions founded to cure venereal disease and to rescue fallen women in the eighteenth century. The London Lock Hospital had been created by

\footnotetext{
2. The Contagious Diseases Acts of 1864, 1866, and 1869 allowed the police to detain any workingclass woman suspected of being a prostitute. They were taken to a lock hospital or ward to undergo a medical inspection which reformers rightly denounced as the rape of the speculum. If they did not want to submit to the examination they could be sent to prison. After that, if they were found venereally diseased they were kept in hospital for a period of about two months. When they were cured they were released and given a certificate. These laws were a government measure to control the spread of venereal disease and promiscuity among the military population and the rest of society. They were suspended in 1883 and repealed in 1886. (Romero Ruiz 2008: 103-110)
} 
William Bromfield to be the first of the many specialist hospitals in London. ${ }^{3}$ The perception of the need to cure the undeserving sick who suffered from venereal disease and of the spread of an illness which was affecting various sectors in Victorian society was behind its erection, according to the opinion of the times. The word lock implied a social evil which respectable society perceived as a peril. ${ }^{4}$ The Hospital was to be run by public subscription which entitled subscribers to control the management of the institution as Governors, but legacies and donations were also welcome. Governors had the prerogative to recommend patients for admission in the first stages of the Hospital, and the need for an institution of this sort was repetitively rehearsed in the pages of many Annual Reports and Accounts, as in those for 1837 , where it is stated:

The malady, to the cure of which the Lock Hospital is appropriated, peculiarly requires medical assistance; and if neglected, or, improperly treated, it must terminate fatally by the most dreadful progress of lingering sufferings... We may indeed consider the dire distemper itself, as a declaration how greatly and holy God abhors licentiousness; yet hath he mercifully provided medicines which seldom fail, when judiciously used, to eradicate it completely. (MS0022/3/8, RCSE Library)

Accounts of the Lock Hospital and Asylum and Annual Reports were published every year to make it known to the general public how these institutions produced results in the cure of these maladies and in the reform of fallen women. They functioned as propaganda making an appeal to middle-class philanthropists to make a contribution to the running of the Hospital and Asylum. Arguments, from God's abhorrence of the existence of venereal disease and promiscuity to God's compassion for these sinners were used to justify their existence. Also, the idea that many respectable married women and innocent children were infected by dissolute husbands was put forward to appeal to the contributor's compassion. Meetings were also held to obtain extra funds in times of special need (like the construction of new buildings) as well as dinners; similarly, advertisements appeared in the newspapers of the day to appeal for funding.

3. William Bromfield was one of a small group of men, the Surgeons to the Great Hospitals of London, who in the eighteenth century established a tradition of general surgery which was to dominate British surgical practice until well into the twentieth. Surgeon to HRH the Prince of Wales and to St. George's Hospital, he saw the need of a hospital for people with venereal disease, who could not be treated at general hospitals. (Innes Williams 1995: 11-17)

4. The word lock had been used in the Middle Ages and the Renaissance to refer to hospitals where lepers were kept. Leprosy had then been considered a very dangerous malady that had to be contained, and lepers were segregated from the rest of society to avoid the spread of this disease which provoked social panic. 
The Lock Chapel, which had outstanding figures amongst its chaplains and became very popular amongst the middle-class, also made a very important contribution to the running of the Hospital and Asylum. The Chapel was founded by Martin Madan and was completed in $1762 .{ }^{5}$ The evangelical revival became crucial in the success of the Lock Chapel and its role in the salvation of prostitutes and fallen women. With it, moral values were brought to the aristocracy, and the middle-classes which emerged after the process of the Industrial Revolution became very much involved in church-going and philanthropy. Religious services and sermons became an important element in middle-class social and religious life. (Innes Williams 1995: 49)

The London Lock Asylum for the Reception of Penitent Female Patients was established in 1792, and the Chaplain Thomas Scott was the spirit behind this charitable project. ${ }^{6}$ It was funded by a different appeal and list of subscribers, and became a key element in the history of the London Lock till its disappearance in the twentieth century. (Innes Williams 1995: 57) The Lock Asylum became very popular, but its degree of success in reforming deviant women was not as impressive as was expected. Only young women who were not hardened prostitutes were admitted, and the theory of the double standard, which became so powerful in the nineteenth century, was clearly behind the aims of this asylum which tried to reproduce the structure of a middle-class home. Hence, a statement like this is made in the Account for the Lock Asylum of 1841:

But while the male patients when cured, return to their former occupations, without any peculiar obstacle to their reformation, most of the women are of that class whose misery and baneful influence have been noticed; many of them have no method of subsistence but by prostitution, and can procure no lodging but in a house of infamy. These have scarcely no alternative, but of starving on the one hand, or returning to their former practices on the other. (MS0022/3/8, RCSE Library)

As a consequence, it was women who had to be the objects of reform and religious indoctrination and of instruction for a decent working-class job. They were the ones responsible for the spread of illness and sexual promiscuity and the ones who had to be secluded. This idea was behind the medical discourse of

5. Martin Madan was appointed Chaplain to the London Lock Hospital in 1758, and one year later he obtained permission from the Board to transform the men's ward into a Chapel. Through it, he gave the London Lock a source of income and introduced the evangelical element. He resigned in 1776. (Innes Williams 1995: 35)

6. When Rev. Thomas Scott became Chaplain, he realized that it was difficult for girls leaving the Hospital to avoid former friends, and that an Asylum should be created. The decision to found the Asylum was made at a meeting on 18 April 1789. 
the time: doctors like William Acton ${ }^{7}$ and others believed that it was women and not men that were the source of contagion for venereal disease, and prostitutes were defined as The Great Social Evil and as women who had a sexual impulse like men. This notion was also behind the spirit of the Contagious Diseases Acts above mentioned, as it was women who had to submit to medical examination and control to avoid the sexual and moral contamination of the rest of society, whereas men were not subjected to this process of degradation and incarceration. According to many women reformers and feminists of the time, like Josephine Butler and Florence Nightingale ${ }^{8}$, this practice was unfair since the blame was put on one half of the human race, while ignoring and in effect sanctioning the responsibility of the other.

\section{THE LAWS OF THE LONDON LOCK HOSPITAL AND ASYLUM OF 1840, REVISED 1848}

The Laws of the London Lock Hospital and Asylum of 1840 and revised in 1848 are part of a manuscript kept in the Hunterian Library at the Royal College of Surgeons of England. They were published in a little book with blue covers by Chapman Printer, Star Street, Paddington. The Institution was under the patronage of HRH the Duke of Cambridge, with the Duke of Sutherland as its President.? The version that this manuscript contains is that of June 1848, with the Asylum Regulations at the end. (MS0022/5/2, RCSE Library) The book contains notes on the margins written in the 1860's with corrections, suppressions and additions to these rules, and two other books of rules -- for 1814 and 1890 -- have survived.

The first section of the Laws is devoted to the Governing Body, which consists of a Patron, a President, twelve Vice-Presidents, two Treasurers and a number of Governors. Governors had to contribute yearly with a minimum of five guineas,

\footnotetext{
7. William Acton was a very well-known doctor and an advocate of the Contagious Diseases Acts. He supported the theory of the double-standard and the single-code of sexual morality. He published a book entitled Prostitution Considered in its Moral, Social and Sanitary Aspects in 1857, which became very popular.

8. Josephine Butler was a middle-class reformer and feminist who spent her years after the death of her only daughter on the rescue of prostitutes and fallen women; she became the leader of the Repeal Campaign against the application of the Contagious Diseases Acts. When these Acts were finally abolished she devoted her last years to the campaign for legal reform to put an end to child prostitution and sexual abuse which culminated in the passing of the Criminal Law Amendment Act of 1885. Florence Nightingale, known as "The Lady with the Lamp", was a feminist and the founder of the nursing profession, and a supporter of the Repeal Campaign and women's rights.

9. Members of the Royal Family and the aristocracy were patrons and presidents of the Institution - as they were, of course, of a wide range of hospitals and other charitable institutions.
} 
becoming Subscribers, or to give a donation of 50 pounds or more, becoming Benefactors. They had the right to attend at all Weekly, Quarterly and Special Boards and to speak and vote on all questions. They could recommend a number of in-patients and out-patients.

This was especially significant as a meeting of the Weekly Board was held every Thursday, where patients were admitted following the recommendation of letters brought by Governors, although urgent cases without letters could be admitted by the Surgeon. Also patients were discharged according to the reports of the physicians and surgeons. Every month a deputation was appointed "to inspect the wards and receive any complaints from the patients". (MS0022/5/2, RCSE Library) This was one of the very few ways in which the patients' voices could be heard. The Weekly Board had also to examine and order the payment of all the bills, and to purchase the things the Hospital needed, ordering repairs and alterations when they were deemed necessary. However, financial matters were in the hands of the Treasurers, the Trustees and the Collector. Important posts were those of the Chaplain and Secretary.

The Chaplain was a crucial figure at the London Lock. Rev. James Gibson and Rev. Thomas Garnier were chaplains at the time these rules were approved and then revised. ${ }^{10}$ Chaplains started all meetings with prayers and had to be in full orders in the Church of England. They were appointed by the Trustees of the Lock Chapel and were very influential figures. From the pulpit and with their sermons they contributed to the financial support of the Institution. However, their most important role was the salvation of sinners. Although forgiveness was emphasized, punishment remained essential in asylums for fallen women and prostitutes who should repent their past life and ask forgiveness for their sins. The focus of rescue work became redemption and to reclaim the sinner's soul, and this idea would promote the concept of the prostitute as a victim of social injustice and "the parable of the lost sheep was used constantly as a comparison between rescue work, prostitution and religion". (Bartley 2000: 31-33) At the London Lock Hospital, the Chaplain had to provide the patients with religious services and instruction. He had to visit the wards once a week "in order to perform all such religious offices, either by consolation or exhortation, or administration of the sacrament of the Lord's Supper". (MS0022/5/2, RCSE Library) Among his functions was to recommend religious books to patients, so that these sinners could be rescued and saved, and

10. Rev. James Gibson was appointed Chaplain in 1811 and resigned in 1818; he was appointed Chaplain again in 1832 till 1847 when Rev. Thomas Garnier succeeded him. (MS0022/6/3, RCSE Library) 
to inform the Weekly Board of "all abuses and irregularities" that he witnessed. (MS0022/5/2, RCSE Library)

The Secretary was another crucial figure in the London Lock Hospital: his functions were closely connected with those of the Matron. Apart from being the Secretary at all meetings of the different Boards and Committees, he was responsible for all the official documents of the Institution such as letters, accounts, books and deeds. He also had to keep a list of all the Governors, Subscribers and Benefactors, and to enter new or amended rules in the book for the Laws of the London Lock Hospital and Asylum. The rules, therefore, were a dynamic set of regulations that could be changed, and additions and suppressions could also be made to them.

The Secretary had a salary and lived in the premises. He was in charge of all the businesses related to the male patients and the male servants and nurses in the male wards in the hospital. This meant that he had to inspect and visit these wards at least once a day, and he had to attend the Chapel of the Hospital every Sunday, together with the patients, nurses and servants in the male wards. According to these Laws, "He shall be master of the household, and as such, shall, in conjunction with the matron, be responsible to the Weekly Board for the order and good government of the household in every respect". (MS0022/5/2, RCSE Library) That is, he was like a kind of paterfamilias, representing masculine power according to the principles of $19^{\text {th }}$ century England. From these rules concerning the Secretary who was in charge of the male wards, and from those concerning the Matron who was in charge of the female, we can observe that the principle of segregation was kept at the London Lock Hospital, which was the common practice in those days, keeping male and female patients apart, and at the same time the religious principles of the Church of England governed the rules and routines of this Institution.

The Matron was another outstanding figure in the London Lock. Together with the Secretary, she had to reside in the House, and she was paid a salary. She had to fulfil a series of requisites: she had to be single and without family, to be between thirty and forty-five at the time of her election and would cease to be matron at the age of sixty-five. She had to be a decent woman of good reputation and a member of the Church of England, reproducing then the middle-class moral standards. Like the Secretary, she had to visit the female wards once a day and read aloud the rules to nurses and patients at least once a week; all the nurses and female servants were under her supervision, and she was also in charge of the Asylum inmates. She represented the female authority that was sanctioned in all Victorian discourses, limiting her functions to the private sphere and keeping her 
appropriate gender roles. She had to have an irreproachable behaviour and be an example for the female inmates.

The Matron was a very important and very influential figure for female patients and inmates. In many of the Annual Reports and Accounts we can read letters of mistresses to the Matron giving a progress-report on an ex-inmate who was working as a servant in her household, and letters from the girls to the Matron telling her how well they were doing after they had left the Home, which obviously had a propagandistic intention. Thus, in the Account of the Lock Hospital and the Lock Asylum of 1837, we can find a letter from a mistress to the Matron that reads as follows:

My dear Madam,

I have much satisfaction in informing you, the conduct of M.A.W. during her residence with me has been most exemplary; she is an amiable and trustworthy young woman, and it will give me great pleasure to see her good conduct rewarded by the members of your benevolent institution. (MS0022/3/8, RCSE Library)

Girls were given a pecuniary reward after remaining for a time in service and for their good behaviour. We must bear in mind that one of the roles of the Asylum was to follow its former inmates' careers and to care for their welfare. Also, matrons were quite often regarded as mothers by some former inmates, as there were many of them who were orphans or came from broken families. So it is not surprising that it was really difficult to find a suitable person for the post, and the poor salary in most cases made things worse. The Matron had to be understanding but firm at the same time, in order to teach girls religious values of submission and fear of God, and a decent working-class profession. (Finnegan 1979: 182)

In the London Lock Asylum, inmates were taught laundry-work which paid in part for their maintenance and later on sewing and embroidery were added. The Matron had to supervise this work and to keep an inventory of all furniture, wares, bedding, linen, etc., and was responsible for the cleanliness of the Hospital. The Matron had also the obligation to go to the Chapel every Sunday together with the nurses and patients in the female wards and the female servants.

The medical officers at the London Lock Hospital, like the Consulting Physician and Physician, the Surgeons and Assistant Surgeon, the Visiting Apothecaries and the Apothecary, the House Surgeon, the Pupils and the Nurses, had to follow their own rules too. ${ }^{11}$ All patients had to be seen by a Surgeon or Assistant Surgeon

11. Pupils were medical students in the nineteenth century who paid a sum of money to established surgeons or physicians to be instructed at various London hospitals so that they could start a practice of their own. 
twice a week, or even oftener in more urgent or serious cases, except out-patients who were attended less frequently. One of the Surgeons would examine all the people applying to be admitted into the Hospital every Thursday and would give a report to the Weekly Board of those who should be accepted as patients. Surgeons had the power to order admission of urgent cases that then had to be sanctioned by the same Weekly Board. Also, the House Surgeon had to report to the Board the number of vacant beds, of patients admitted during the week and of those about to be discharged in that period.

Nurses were difficult to recruit and their behaviour had to be carefully checked as most of them came from the working-classes and were not trained in most cases. The nursing profession was not consolidated till the last decades of the nineteenth century. In the London Lock Hospital, nurses were appointed by the Matron, and there were also Head Nurses and Night Nurses. They had to be between thirty and forty-five at the time of their appointment, and had to be literate. The nurses had to obey the orders of the Matron and Secretary, and the fact that the words "Any nurse receiving any sum of money, treat, present or gratuity, from any patient, in respect of the services of such a Nurse in the Hospital, shall be dismissed, and shall be incapable of re-appointment" (MS0022/5/2, RCSE Library) are included in the regulations show that either there must have been problems with the nurses' behaviour or that middle-class prejudices against the working-classes are deeply embedded in these norms.

These regulations also reproduced the gender division that was found in Victorian times for the world of work. In the London Lock Hospital and Asylum, women fulfilled jobs connected with their sphere and their caring, tendering nature, that is, they were matrons, servants or nurses; men held posts associated with the secretarial, managerial or medical professions, following the long-established patriarchal division of gender roles that were reproduced in the middle-class family and in society in general.

As far as patients were concerned, they were in the Hospital between six and eight weeks. The same as in earlier times, most cases were suffering from secondary or tertiary syphilis, chancroid, complicated gonorrhoea or venereal warts ${ }^{12}$, according to Innes Williams. (1995: 67-68) Most female patients came from various parishes in London and the provinces. They were in their late teens and early twenties and had been in domestic service before moving into prostitution. They got infected

12. There is a first stage in syphilis known as "primary", but at this stage patients did not go to the Lock Hospital. 
after roughly two years in the trade and many of them claimed to be orphans. A minority were married women infected by their promiscuous husbands; only a few were widows or under the age of sixteen. There were occasional miscarriages in the wards, but pregnant women were not usually accepted and children are hardly mentioned. ${ }^{13}$ Such mothers, as has been mentioned, were sent to the workhouse. Male patients in the London Lock were usually older than girls, their age usually ranging from eighteen to their thirties. Most came from outside London, were single and working-class. (Innes Williams 1995: 68-69) Most patients in the London Lock Hospital were therefore working-class, and men and women from the superior classes who suffered form venereal disease went to private doctors to obtain treatment. The women patients were considered deviant, promiscuous and riotous and the perception of their lives of sin was biased by middle-class standards; only some married women and mothers were regarded as decent by the authorities running the Institution. In the regulations for 1814, activities usually associated with the working-classes like gambling, drinking, swearing or rioting were forbidden for the patients, being an example of the prejudices that the bourgeoisie had against the lower orders and which frequently categorised them as the undeserving poor. (MS0022/5/3, RCSE Library)

The last group of people under these regulations were the Porter and other Servants, who were all working-class and were at the bottom of the job hierarchy that existed in the London Lock Hospital and Asylum.

The Asylum Regulations came at the end of the Laws and were thirteen in number. About one quarter of the girls released from the London Lock Hospital entered the Lock Asylum. The first of the Asylum regulations said that "the object of the Institution is to afford a refuge to such of the female Patients of the Lock Hospital, as appear sincerely desirous of quitting their evil courses". (MS0022/5/2, RCSE Library) From this statement we can deduce that only female patients from the Hospital were admitted, and the selection criteria was that they had to show a deep feeling of repentance and a serious desire of being reformed. It was the Chaplain who decided "after careful examination" which girls deserved the chance to be religiously instructed and to be taught a decent occupation before being sent out to service or restored to family or friends. The task of the London Lock Asylum

13. Nonetheless, among the manuscripts of the Lock Hospital there are some drawings of patients painted by J. Holt in the middle of the nineteenth century, MS0022/6/3, where some children with venereal disease can be found, like the child of Mary Ann Angus (22 May 1850) and the child of Eliza Morris (20 April 1850). 
did not finish with the girls being found a respectable situation, but their careers and future lives were closely followed after they left the Institution. This task was done by the Matron and the Ladies' Committee, who were responsible for the welfare of ex-mates.

The girls admitted had to go through a probation period that lasted two months, and after that they stayed in the Asylum for about two years, but some of them left after only a few weeks; it seems that some of them could not stand the strict discipline, the hard work and the sense of feeling sinful and unclean that was supposed to be instilled into them, however, their moral values and their views on sex were different from those of their middle-class reformers. (Innes Williams 1995: 70-71) They had to do laundry work, which has been interpreted as a kind of process of cleansing of their moral sins and a way of redemption from their pasts. The aim was also that they could contribute to the maintenance of the institution. They were therefore detained inside the Asylum and they lost any contact with their families or friends who could only visit them under the approval and the supervision of the Matron. Every contact with the world outside was cut and it was almost impossible to leave these places during the probation period and the two-year period of confinement; punishment and expulsion were the usual measures taken to subjugate them. The education and training they received was oriented to the re-inclusion of these young women again in Victorian society, following the patterns of jobs that were seen as appropriate for working-class women. They were not taught literacy and numeracy, which would have enabled them to have better future prospects and a better education. Nothing is mentioned about inmates wearing uniforms, although it was compulsory in many reform institutions and in workhouses.

The management of this Institution was then, according to these regulations, in the hands of the Chaplain and a Committee of Ladies who would supervise everything and meet once a month to make arrangements and take decisions concerning the inmates significantly called Penitents. Some of them would visit the Asylum every week, and their control over the girls went to the extent that they granted them rewards for good behaviour after they left. Homes and asylums for girls under sixteen were established after the 1830's, following the Victorian trend of segregation and classification. (Jackson 2000: 132-137) As the century progressed, these institutions became more specialized and divisions of inmates according to age, class or health were undertaken in bigger premises. All of them were subject to a process of seclusion and of transformation of their identities to become restored to society, following middle-class standards. Aspects such as 
incarceration, disruption of families, indoctrination, education and training were key elements in the process of re-inclusion of these deviant women in Victorian society, as we have seen. (Mahood 1990: 81-83)

\section{CONCLUSION}

This paper has examined The Laws of the London Lock Hospital and Asylum of 1840 and revised in 1848 against the background of the long-term histories of this and similar institutions. Both male and female patients were kept in lock hospitals to be cured from venereal disease; men and women were treated in different wards so that they had no contact and the spread of promiscuity was avoided, although this measure was not invariably successful. Nonetheless, sexual discrimination was even more evident when it came to moral reformation; men were released when healed and allowed to return to their former jobs and relatives, but women did not have anywhere to go to recover a decent life. They did not have decent working-class jobs --they were ex-prostitutes-- family or appropriate friends, not even a place where to dwell.

Through the Hospital and Asylum regulations, it can be seen that women were moulded according to middle-class assumptions of respectability and to religious values which put the emphasis on a life of exclusion and atonement for these fallen women. The aim was to indoctrinate these women and prepare them for a decent job to be included again in society. As a consequence, only when an inmate had changed completely according to middle-class standards of feminine propriety, could she be released, and the estimated length of time for seclusion was two years to achieve the expected results. The home reproduced the paternalistic structure of bourgeois society, the Chaplain and other male authorities playing the role of the father and the Matron and other female staff representing the mother-figure and setting an example of appropriate behaviour.

The intention behind the control and discipline exercised on these women on the part of the middle-class reformers and philanthropists and the Church was probably good, but the failure of these institutions was attributable to the fact that many of these women did not perceive themselves as sinful and had different habits and beliefs regarding sex and premarital relations. Purity and chastity were middle-class conceptions that did not have the same connotations for women of the labouring classes; it was really hard for these women to return to a life of hardness and misery becoming servants in middle-class households, a life even harder than prostitution.

In the case of the London Lock Hospital and Asylum, the regulations reflect all these ideas. Men and women were treated differently and were kept apart, the 
religious element was present in all the activities of the Institution, a paternalistic structure could be observed, a stern control was kept over the inmates, especially over women, and middle-class and religious values were present in all the efforts of reform of fallen women made at the Lock Asylum. The aim was to return decent and healthy working-class individuals to society. The important decisions were taken by male authorities, except for the Matron and the Ladies' Committee for the Asylum, and always reproducing the gender roles sanctioned by these middle-class reformers. These philanthropists devoted an important part of their time and efforts to improve and restore deviant elements but without detaching themselves from the social and moral bias in which they were immersed, which was in fact what could be expected of them.

\section{REFERENCES}

An Abstract of the Rules and Orders for the Government of the Lock Hospital, near Hyde Park Corner, Instituted July 4, 1746, for the Relief of Venereal Patients Only, By Order of the Annual General Court held April 21, 1814, N. Meredith, Secretary, Printed by Meredith and Son, Mount-Street, Lambeth, The Hunterian Library, Royal College of Surgeons of England, London, MS0022/5/3.

An Account of the Nature and Intention of the Lock Asylum, for the Reception of Penitent Female Patients when Discharged from the Lock Hospital: with an Abstract of the Accounts from the First Institution, to LADY-DAY, 1837. Also the Code of Regulations, with a List of Benefactors and Subscribers, 1837, The Hunterian Library, Royal College of Surgeons of England, London, MS0022/3/8.

An Account of the Lock Hospital; to Which is Added an Account of the Lock Asylum, 1837, The Hunterian Library, Royal College of Surgeons of England, London, MS0022/3/8.

Account for the Lock Hospital and Asylum of 1841, The Hunterian Library, Royal College of Surgeons of England, London, MS0022/3/8.

Bartley, P. 2000. Prostitution: Prevention and Reform in England, 1860-1914. London and New York: Routledge.

Finnegan, F. 1979. Poverty and Prostitution: A Study of Victorian Prostitutes in York. Cambridge: Cambridge University Press.

Innes Williams, D. 1995. The London Lock: A Charitable Hospital, 1746-1952. London and New York: Royal Society of Medicine Press Ltd.

Jackson, L. 2000. Child Sexual Abuse in Victorian England. Routledge: London and New York. 
Laws of the London Lock Hospital and Asylum, Revised (1840), 1848, The Hunterian Library, Royal College of Surgeons of England, London, MS0022/5/2.

Longmate, N. 2003. The Workhouse: A Social History. London: Pimlico.

Mahood, L. 1990. The Magdalenes: Prostitution in the Nineteenth Century. London and New York: Routledge.

Mitchell, S. 1981. The Fallen Angel: Chastity, Class and Women's Reading 18351880. Bowling Green, Ohio: Bowling Green University Popular Press.

Nead, L. 1988. Myths of Sexuality: Representations of Women in Victorian Britain. London: Blackwell.

Romero Ruiz, M.I. 2008. "The Plots of History and the Rape of the Speculum: The Contagious Diseases Acts and the Violation of Women's Rights". Historia $y$ representación en la cultura global. Eds. C. Rodríguez González and R. Valdés Mirayes. Oviedo: KRK Ediciones, 103-110.

Walkowitz, J.R. 1991 (1980). Prostitution and Victorian Society: Women, Class and the State. Cambridge: Cambridge University Press. 